\title{
PENGEMBANGAN REPOSITORI INSTITUSI SEBAGAI SARANA KOMUNIKASI ILMIAH PADA UNIVERSITAS ISLAM NEGERI (UIN) IMAM BONJOL PADANG
}

\author{
Arwendria*, Ariska Oktavia** \\ *Program Studi Ilmu Perpustakaan, UIN Imam Bonjol Padang \\ **Program Studi Ilmu Perpustakaan dan Informasi, Universitas Indonesia \\ Email: arwendriadahlan@gmail.com,ariskaokt.16@gmail.com
}

(Submitted: 18-02-2019, Revised: 04-03-2019, Accepted: 01-12-2019)

DOI: $10.24252 /$ kah.v7i2a5

\begin{abstract}
ABSTRAK: Penelitian ini bertujuan untuk mengeksplorasi dan mendeskripsikan persepsi pustakawan dan dosen, serta tantangan dan kesulitan secara teknis dalam mengelola dan mengembangkan repositori institusi untuk mendukung komunikasi ilmiah. Kajian berfokus di Perpustakaan UIN Imam Bonjol Padang. Metode penelitian yang digunakan adalah campuran (mixed-methods) yang memadukan pendekatan kualitatif dan kuantitatif. Hasilnya menunjukkan bahwa pustakawan belum sepenuhnya memahami tentang konsep komunikasi ilmiah. Di sisi lain, dosen belum yakin dengan kompetensi pustakawan dalam mengelola repositori institusi. Masalah teknis juga menjadi tantangan dalam pengembangan repositori institusi sebagai sarana komunikasi ilmiah. Dibutuhkan kerja sama antara dosen dan pustakawan dalam mengembangkan komunikasi ilmiah. Kerja sama tersebut melalui kebijakan tertulis dalam bentuk peraturan rektor. Selain itu, UPT Perpustakaan UIN Imam Bonjol Padang harus mengembangkan pola komunikasi yang lebih baik dengan UPT TIPD.
\end{abstract}

Kata kunci: Pengembangan koleksi; komunikasi ilmiah; repositori institusi

THE DEVELOPMENT OF INSTITUTIONAL REPOSITORY AS SCIENTIFIC COMMUNICATION IN UNIVERSITAS ISLAM NEGERI (UIN) IMAM BONJOL PADANG

\begin{abstract}
The purpose of this study was to explore and describe the perceptions of librarians and lecturers, as well as the challenges and technical difficulties in managing and in developing institutional repositories to support scientific communication. The study was focused on the Imam Bonjol UIN Padang Library. The research methods were used are mixed (mixed-methods) which combine qualitative and quantitative approaches. The results showed that librarians do not fully understand the concept of scientific communication. On the other hand, lecturers are not yet convinced of the librarian's competence in managing institutional repositories. Technical problems were also a challenge in the development of institutional repositories as a means of scientific communication. Cooperation between lecturers and librarians was needed in developing scientific communication. The cooperation was through written policies in the form of rector regulations. Besides that, UPT Library UPT Imam Bonjol Padang must develop a better communication pattern with UPT TIPD.
\end{abstract}

Keywords: Collection development; scientific communication; institutional repository

\section{PENDAHULUAN}

Evolusi komunikasi ilmiah di era digital tidak saja menghadirkan tantangan baru bagi perpustakaan, tetapi juga menciptakan peluang baru bagi perpustakaan untuk berkontribusi besar terhadap penelitian dan pengetahuan (Griffin, 2013). Namun, istilah komunikasi ilmiah tersebut memiliki berbagai definisi, tergantung dari sudut pandang masing-masing. Sauer 
(2009) menggambarkan komunikasi ilmiah sebagai serangkaian kegiatan seputar "penciptaan, transformasi, penyebaran dan pelestarian pengetahuan yang berkaitan dengan pengajaran, penelitian dan kegiatan ilmiah." Mulligan (2015) menjelaskan komunikasi ilmiah tersebut sebagai suatu sistem penciptaan penelitian dan tulisan ilmiah, evaluasi mutu, penyebaran informasi, dan pelestarian untuk digunakan di masa yang akan datang.

Komunikasi ilmiah selalu menjadi prioritas bagi perpustakaan perguruan tinggi, karena misi dari perpustakaan perguruan tinggi secara historis terfokus pada pengadaan koleksi yang dipublikasikan dan melanggan basis data (Hixson, 2006). Namun sesuai dengan perkembangannya, komunikasi ilmiah telah berubah karena sejumlah faktor. Pada awal abad 21, kemajuan teknologi menyebabkan biaya penyimpanan online menurun drastis. Pada saat yang sama, standar baru diciptakan untuk memperoleh arsip metadata terbuka (open archives metadata), sehingga lebih mudah dan efisien untuk mengunggah konten ke web, dan pengembangan sistem repositori open source (Lynch, 2003).

Ironisnya, perpustakaan sebagai institusi informasi memiliki peran terbatas untuk mengorganisasikan, mengendalikan, dan menyebarluaskan informasi kepada para ilmuwan. American Council of Learned Societies (ACLS) meneliti para ilmuwan bidang humaniora dan ilmu sosial tentang pandangannya terhadap perpustakaan dan komputer, serta proses penelitian dan publikasi. Temuan utamanya sangat mengejutkan. Sebagian besar para ilmuwan tidak mampu mengikuti perkembangan literatur di bidangnya. Bahkan para ilmuwan tersebut tidak memprioritaskan perpustakaan dalam daftar sumber daya yang diperlukan untuk penelitiannya, dan tidak menggunakan teknologi yang ditawarkan perpustakaan untuk mengakses informasi (Epp \& Segal, 1987).

Pada tahun 2010, Association of College and Research Libraries (ACRL) mengidentifikasi komunikasi ilmiah sebagai tren teratas pada pustakawan perguruan tinggi berdasarkan pertumbuhan akses/produk sumber terbuka, pertumbuhan koleksi digital yang dibuat secara lokal, peningkatan kompleksitas masalah perizinan, dan masalah produk hukum lainnya. Sebagai tanggapan terhadap masalah tersebut, perpustakaan harus melakukan reposisi untuk fokus pada komunikasi ilmiah.

"Kompetensi komunikasi ilmiah semakin penting dalam perpustakaan penelitian. Pertama, menciptakan posisi spesialis yang akan mengembangkan program dan layanan untuk mendukung komunikasi ilmiah. Kedua, pustakawan harus fasih dalam bahasa komunikasi ilmiah dan dapat mengatasi peluang dan tantangannya. Dengan demikian, literasi komunikasi ilmiah menjadi kompetensi inti bagi pustakawan perguruan tinggi" (Bonn, 2014: 132).

Pada tahun 2017, UPT Perpustakaan Universitas Islam Negeri (UIN) Imam Bonjol Padang telah berupaya mengembangkan koleksinya sesuai dengan perkembangan teknologi informasi dan komunikasi (TIK). Upaya tersebut dapat dilihat dari pengembangan repositori institusi (http://repository.uinib.ac.id) untuk memperkuat koleksi perpustakaannya. Inisiatif tersebut dilakukan karena semakin terbatasnya anggaran pengadaan koleksi, sementara di sisi lain perpustakaan harus mengembangkan koleksi sesuai dengan kebutuhan pemustakanya.

Namun, mengembangkan pemahaman yang lebih holistik terhadap tantangan dan hambatan yang dihadapi oleh UPT Perpustakaan UIN Imam Bonjol Padang untuk mengatasi faktor-faktor yang menghambat pemustaka berpartisipasi dan mempromosikan. Pemahaman tersebut sangat diperlukan untuk meningkatkan layanan repositori institusi sehingga dapat memuaskan pemustakanya. Penelitian ini bermaksud untuk mengeksplorasi dan mendeskripsikan persepsi pustakawan dan dosen, serta tantangan dan kesulitan secara teknis dalam mengelola repositori institusi.

\section{TINJAUAN PUSTAKA}

\section{a. Komunikasi Ilmiah}

Tidak ada definisi tunggal dari istilah "komunikasi ilmiah". Kadang-kadang didefinisikan secara sempit berupa literatur peer-review yang diterbitkan setelah selesainya suatu penelitian (Rowlands, Nichols, dan Huntington 2004), tetapi definisi yang lebih luas mencakup semua komunikasi di antara rekan sejawat (Harnad, 1995). Borgman (2000) mendeskripsikan komunikasi ilmiah sebagai "studi tentang cara ilmuwan dalam bidang apa pun (misalnya ilmu 
fisika, biologis, sosial dan perilaku, humaniora dan teknologi) menggunakan dan menyebarkan informasi melalui saluran formal dan informal. Johnson (2014) mendefinisikan komunikasi ilmiah sebagai suatu proses pertukaran penemuan, ide, dan informasi melalui akses terbuka. Lanjutnya, "studi tentang komunikasi ilmiah termasuk pertumbuhan informasi ilmiah, hubungan antara bidang penelitian dan disiplin ilmu, kebutuhan informasi dan penggunaan informasi oleh kelompok dan pengguna individu, dan hubungan antara metode komunikasi formal dan informal".

Komunikasi ilmiah dapat dilihat sebagai proses di mana hasil penelitian tersedia melalui publikasi dan pelestarian. Computer Mediated Communication (CMC) telah mendefinisikan kembali komunikasi ilmiah. Literatur CMC mengeksplorasi cara jaringan komputer digunakan untuk berkomunikasi, terlepas dari jurnal cetak (Peek and Pomerantz, 1998). Komunikasi elektronik secara ilmiah mencakup distribusi artikel, makalah penelitian, dan pesan melalui sarana elektronik sebagai kebalikan dari distribusinya melalui media cetak. Lyman dan Chodorow (1998) menegaskan bahwa komunikasi ilmiah semakin penting ketika teknologi informasi digunakan dalam penelitian ilmiah. Mereka mengamati bahwa komunikasi ilmiah adalah istilah "diciptakan untuk membingkai, baik publikasi cetak dan komunikasi digital dalam skema fungsional tunggal." ACRL (2004) mendefinisikan komunikasi ilmiah sebagai "sistem penciptaan penelitian dan tulisan ilmiah lainnya, dievaluasi kualitasnya, disebarkan ke komunitas ilmiah, dan dilestarikan untuk digunakan di masa yang akan datang. Sistem ini mencakup sarana komunikasi formal, seperti publikasi dalam jurnal yang ditelaah oleh rekan sejawat, dan saluran informal, seperti listserv elektronik."

Komunikasi melalui sarana informal termasuk diskusi tatap muka, pertukaran komunikasi pribadi, berbagi pandangan, pendapat, dan lain-lain. Istilah "invisible college" kadang-kadang digunakan untuk menggambarkan jaringan komunikasi informal tersebut (de Solla Price, 1963). Saluran yang dibangun sangat cepat dan mudah. Peneliti baru mungkin kekurangan jaringan informal tersebut. Komunikasi formal menggunakan sarana umum, seperti buku, jurnal dan monograf. Keuntungan dari saluran formal adalah:

- informasi dapat disebarluaskan ke kelompok pembaca yang tersebar luas;

- informasi terperinci, seperti deskripsi metode, tabel, diagram, hasil, dan lain-lain dapat dengan mudah diberikan;

- dokumen tercetak berisi informasi yang dapat diperiksa dan diverifikasi secara kritis;

- dokumen dapat dengan mudah dirujuk bila diperlukan; dan

- dokumen yang diterbitkan menyediakan sarana untuk membangun "prioritas" kerja akademis, dan dengan demikian berkontribusi membangun prestasi akademis bagi penulis.

Komunikasi ilmiah formal dapat meneliti artikel, surat, memo, konferensi, laporan teknis, monograf, buku yang diedit, dan sebagainya. Komunikasi elektronik secara ilmiah menggunakan sejumlah genre. Kling dan Callahan (2003) mengkategorikannya sebagai:

- literatur penelitian sosial dan sosio-teknis seperti jurnal, monograf penelitian, konferensi penelitian khusus;

- literatur penelitian teknologi yang mencakup pemeriksaan analitis standar teknologi dan strategi desain;

- literatur praktisi (penulisan profesional) di mana pembaca utamanya termasuk penerbit, pustakawan, administrator akademik dan dosen yang dapat mempublikasikan di emedia, mengatur koleksi elektronik, mengevaluasi publikasi elektronik tersebut; dan

- forum elektronik ilmiah.

Literatur ilmiah utama adalah literatur penelitian sosial dan sosio-teknis, terutama jurnal, yang memberikan informasi terkini, canggih, dan ditelaah oleh rekan sejawat. Web telah mengubah penerbitan jurnal. Para ilmuwan didorong untuk memanfaatkan jurnal elektronik secara serius sebagai peluang untuk komunikasi yang lebih cepat, lebih mudah diakses, dan bahkan lebih murah. Karena jurnal cetak telah diganti dengan versi elektronik, sebagian besar 
penerbit telah menerima model komunikasi ilmiah tersebut. Dengan demikian, tak salah the Board of National Enquiry merekomendasikan dan memprediksi pertukaran pengetahuan ilmiah di masa depan di Amerika Serikat sebagai "New library like services will be offered by publishers and wholesalers, scholars will enter materials directly into libraries, libraries will perform publisherlike or bookstorelike functions." (Scholarly Communication: The Report of the National Enquiry, 1979).

\section{b. Penerbitan Ilmiah}

Pengetahuan merupakan proses komunikasi karena berasal dari penyelidikan dan penemuan. Sistem komunikasi ilmiah mencakup interaksi dari banyak orang yang membuat, mengubah, mendistribusikan, mengumpulkan, melestarikan, menyediakan, dan menggunakan penelitian para ilmuwan dan untuk mengajar, penelitian tambahan, dan kegiatan ilmiah lainnya (Johnson, 2014). Lebih lanjut ditegaskan bahwa penerbitan ilmiah adalah bagian dari komunikasi ilmiah. Hahn (2008) mendefinisikan penerbitan ilmiah sebagai "bagian dari kegiatan komunikasi yang dimediasi melalui penggunaan media yang tahan dalam jangka panjang untuk memperbaiki pengetahuan."

Penerbitan ilmiah adalah sarana formal untuk berkomunikasi dalam komunitas ilmiah (Tenopir \& King 2000). Penerbitan ilmiah setidaknya memuat tiga tujuan dalam konteks komunitas ilmiah, yaitu publisitas, akses dan kepercayaan. Publisitas adalah tempat suatu karya ilmiah diumumkan kepada pemirsa melalui serangkaian kegiatan, dari pengabstrakan dan pengindeksan hingga iklan dan kutipan. Aksesibilitas mengacu pada cara-cara pembaca potensial dapat mengakses karya tersebut. Kepercayaan mengacu pada tingkat "kualitas" suatu karya ilmiah. Kepercayaan dapat diartikan bahwa artikel ilmiah telah ditinjau secara hati-hati dengan membaca dan menilainya oleh rekan-rekan yang berpengetahuan luas (Drott 2006).

Orang-orang yang terlibat dalam penerbitan ilmiah memiliki peran yang berbeda. Misalnya, akademisi dan ilmuwan menulis artikel dan secara paradoks mereka juga menjadi target utama pembaca artikel yang sama. Mereka juga memberikan sertifikasi, melalui peer review, sedangkan jurnal menyediakan registrasi sebuah karya. Beberapa organisasi dan platform teknologi memberikan aksesibilitas, mulai dari penerbit jurnal sendiri melalui departemen pemasaran dan daftar pelanggan, hingga pengindeksan komersial dan organisasi serta abstrak. Pengarsipan disediakan oleh penerbit sampai batas tertentu (tergantung pada fasilitas penyimpanan dan keberlanjutan keberadaan mereka) tetapi juga oleh perpustakaan. Perpustakaan juga menyediakan akses ke pembaca yang lebih luas, melalui akses langsung ke pinjaman publik dan antar perpustakaan serta pengiriman dokumen. Keuntungan selalu dibuat hanya oleh penerbit secara langsung, meskipun orang mungkin berpendapat bahwa akademisi dan sarjana mendapat keuntungan tidak langsung, melalui peningkatan reputasi, hibah, masa jabatan, promosi dan sebagainya (Bjork 2005; Kling \& Callahan 2003; Kling \& McKim 1999; Prosser 2005).

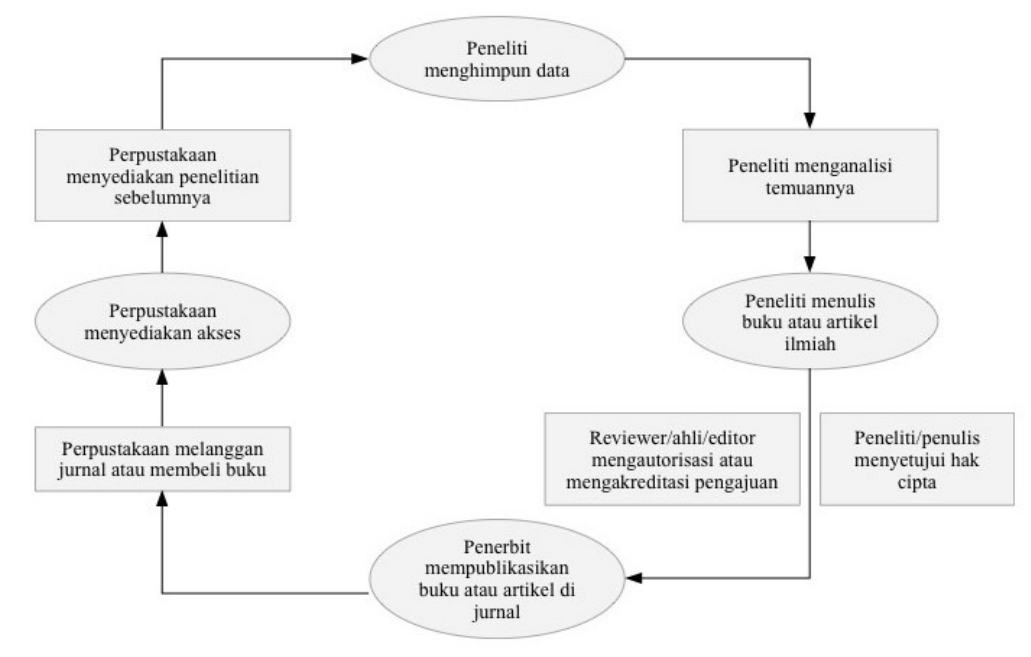

Gambar 1. Sistem penerbitan tradisional (Johnson, 2014: 401) 
Pada gambar 1 dapat dilihat sistem tradisional penerbitan ilmiah sebagai siklus berkelanjutan. Internet dan teknologi berbasis web telah diadopsi sedemikian rupa sehingga penerbitan ilmiah sekarang sebagian besar tersedia secara online di desktop. Walaupun biaya akses ke karya ilmiah belum meningkat, tetapi kebutuhan perpustakaan semakin berkembang, sebagian karena meningkatnya cakupan dan sebagian karena meningkatnya jumlah dan biaya jurnal. Oleh karena itu, meskipun kemajuan teknologi telah mendorong akses, model penerbitan tradisional masih dibutuhkan dalam batas-batas tertentu (Dewatripoint et al. 2006).

Universitas dan lembaga pendanaan eksternal mensubsidi dan membayar biaya penelitian. Dosen dan peneliti membaca karya sebelumnya, mengumpulkan data, melakukan penelitian, dan menganalisis temuannya. Mereka menulis artikel jurnal dan buku yang melaporkan hasil temuan dan analisisnya dan mereka mentransfer kekayaan intelektual tulisannya melalui persetujuan hak cipta kepada penerbit. Dosen, peneliti, dan ahli yang telah meluangkan waktunya (jarang menerima kompensasi keuangan) di dewan editor jurnal meninjau makalah yang diajukan untuk dipublikasikan. Dewan peninjau serupa di media cetak mengevaluasi monograf ilmiah untuk dipublikasikan. Penerbit biasanya menangani copyediting dan tipografi dan bertanggung jawab untuk memproduksi dan mendistribusikan karya cetak tersebut. Perpustakaan perguruan tinggi dan riset membeli publikasi tersebut dan mengorganisasikan, menyebarkan, dan melestarikan karya ilmiah tersebut. Siklus tersebut berlanjut ketika para peneliti berkonsultasi dengan publikasi untuk mengajukan penelitian baru (Johnson, 2014).

Perubahan akses ke karya ilmiah telah mendorong ilmuwan membuat karyanya sendiri yang dapat diakses secara terbuka dan tersedia secara gratis melalui Internet tanpa biaya atau hambatan hukum atau teknis (Budapest Open Access Initiative, 2002). Ilmuwan dapat membuat akses terbuka terhadap karyanya dalam beberapa cara, yang paling umum adalah; memposting karyanya ke situs web mereka sendiri atau ke repositori institusi atau bidang tertentu yang dibuat untuk menyimpan, melestarikan dan menyebarluaskan penelitian mereka (dikenal sebagai self-archiving); atau mempublikasikan dalam jurnal akses terbuka. Karya-karya yang diarsipkan sendiri pada umumnya adalah karya yang diberikan oleh para ilmuwan tanpa mengharapkan bayaran, misalnya karya yang diterbitkan dalam jurnal atau konferensi peerreviewed tradisional. Self-archiving karya tersebut dapat terjadi pada pra-cetak (rancangan yang tidak direvisi, tidak disunting, tidak diterima oleh jurnal) atau pasca-cetak (semua karya pasca publikasi termasuk draf yang diterbitkan secara resmi) (Suber, 2003; Budapest Open Access Initiative, 2002). Karya self-archiving dapat ditampilkan pada halaman web atau di repositori.

\section{c. Repositori Institusi}

Repositori institusi adalah sistem berbasis web yang dirancang untuk mendukung para peneliti dalam menyediakan akses dan memungkinkan komunikasi tanpa batas dari hasil penelitian mereka ke komunitas yang ilmiah dan lebih luas. Repositori kemudian bergantung pada infrastruktur teknologi informasi (TI), internet dan perangkat lunak serta layanan berbasis web untuk memungkinkan mereka menjalankan fungsi mereka dan mencapai tujuan yang dinyatakan dalam penyediaan akses terbuka untuk hasil penelitian ilmiah.

Repositori institusi adalah perpustakaan digital, karena keduanya mengumpulkan dan melestarikan karya digital, tetapi repositori institusi khusus untuk melestarikan dan menyebarluaskan hasil intelektual perguruan tinggi atau lembaga penelitian dan anggota komunitasnya (Adewumi dan Omoregbe, 2011). Lynch (2003) menjabarkan repositori institusi sebagai serangkaian layanan yang disediakan oleh suatu lembaga kepada anggota komunitasnya untuk memungkinkan menyimpan dan menyebarkan hasil intelektualnya.

Secara tradisional output intelektual dari sebuah institusi cenderung dikirim keluar ke penerbit khusus subjek. Berarti karya suatu lembaga dapat tersebar di berbagai penerbit dan pada koleksi perpustakaan yang berbeda. Di sisi lain, repositori institusi memungkinkan sebuah lembaga untuk menyimpan output intelektualnya pada platform yang mendorong berbagi informasi dan juga merupakan sarana yang efektif untuk menampilkan kualitas akademik lembaga tersebut (Yeates, 2003). Sudah menjadi tanggung jawab perguruan tinggi dan lembaga penelitian untuk melestarikan dan membuat output intelektualnya tersedia bagi pemustakanya; tanggung jawab ini keduanya disediakan dengan cara menyiapkan repositori institusi (Lynch, 2003). 
Masalah penting pengembangan repositori institusi sebagai komunikasi ilmiah adalah akses terbuka (open access). Bagi sebagian orang dan institusi, akses terbuka mengacu pada pembuatan artikel atau buku yang digital, online, gratis dan bebas dari sebagian besar pembatasan hak cipta dan lisensi (Hahn \& Wyatt, 2014). Sebagiannya lagi berkomitmen untuk memiliki akses terbuka total, yang memungkinkan konten untuk dipublikasikan ulang atau digunakan kembali (Carroll, 2011). Dalam gerakan akses terbuka, ada dua opsi utama: akses terbuka emas (gold open access) dan akses terbuka hijau (green open access). Dalam akses terbuka emas, penulis biasanya membayar biaya pemrosesan artikel untuk mempublikasikan dalam jurnal akses terbuka. Akses terbuka hijau mengacu pada kemampuan penulis untuk mengarsipkan salinannya sendiri di lokasi lain selain situs web penerbit asli (Björk, Laakso, Welling, \& Paetau, 2013).

Dari berbagai literatur tersebut, dapat dijelaskan bahwa repositori institusi adalah serangkaian layanan yang ditawarkan oleh institusi untuk manajemen dan distribusi output intelektual (seperti penelitian), yang telah dibuat oleh institusi tersebut (Lynch, 2003). Repositori institusi merupakan komponen penting dalam mereformasi komunikasi ilmiah karena dapat mengurangi kekuatan monopoli yang dipegang oleh vendor jurnal dan memberikan kontrol atas pengetahuan kepada institusi akademik yang menciptakannya. Selain itu, repositori institusi dapat berfungsi sebagai indikator nyata untuk menunjukkan kualitas perguruan tinggi yang menghasilkan penelitian selain dapat meningkatkan reputasi perguruan tinggi tersebut (Crow, 2002).

\section{METODOLOGI PENELITIAN}

Penelitian ini menggunakan metode campuran (mixed-methods) yang memadukan pendekatan kualitatif dan kuantitatif. Populasi penelitian terdiri dua kelompok yakni dosen dan pustakawan. Pemilihan responden dilakukan secara snowball purposive sampling terhadap 5 orang dosen dan 8 orang pustakawan. Data penelitian diperoleh melalui wawancara dan kuesioner ringkas tentang definisi komunikasi ilmiah menurut pustakawan. Wawancara dilakukan secara fleksibel sehingga memungkinkan peneliti mengembangkan percakapan berdasarkan jawaban dari responden, untuk menanggapi pernyataan yang dibuat oleh responden, dan bertanya secara spontan, mengklarifikasi atau pertanyaan baru untuk mendapatkan informasi tambahan (Berg, 2009). Selain itu juga dikembangkan kuesioner tentang masalah teknis yang dihadapi oleh pustakawan. Data tersebut kemudian diolah secara deskriptif.

\section{HASIL DAN PEMBAHASAN}

a. Model yang Digunakan

Visi Perpustakaan UIN Imam Bonjol Padang adalah menjadi pusat rujukan Islam di Sumatera Barat. Untuk mewujudkan visi tersebut, maka Perpustakaan UIN Imam Bonjol Padang harus mampu mendukung seluruh siklus komunikasi ilmiah dengan cara menawarkan dukungan profesional kepada para peneliti di setiap tahap penelitian, mulai dari menemukan ide penelitian hingga menerbitkannya. Strategi yang digunakan yaitu siklus tiga tahap dari Utrecth University, yaitu: Penelitian, Buat, Bagikan. 


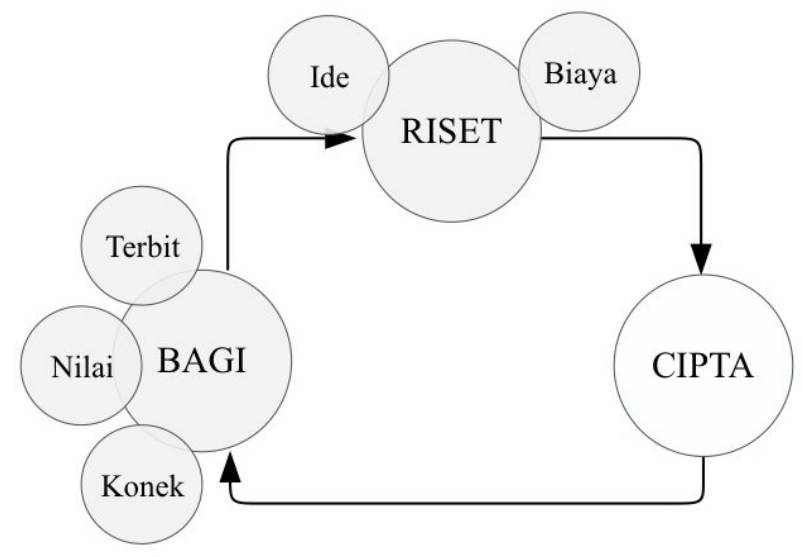

Gambar 2. Siklus tiga tahapan Utrecth University

Perpustakaan UIN Imam Bonjol Padang telah bekerja selama beberapa waktu untuk mengembangkan dukungan untuk semua tahap siklus komunikasi ilmiah. Pada tahun 2017, perpustakaan bekerja sama dengan UPT TIPD meluncurkan Rumah Jurnal Akses Terbuka UIN Imam Bonjol Padang (https://ejournal.uinib.ac.id/) untuk melestarikan data penelitian sivitas akademika UIN Imam Bonjol Padang.

\section{b. Aplikasi yang Digunakan}

Dari hasil wawancara dengan Kepala Perpustakaan UIN Imam Bonjol Padang, Zulfitri, bahwa aplikasi yang digunakan untuk repositori institusi adalah Eprints yang dikembangkan oleh Universitas Southampton pada tahun 2000. Alasan penggunaan perangkat lunak Eprints menurut Zulfitri karena 1) mudah digunakan; 2) fitur pencarian mudah dipahami oleh pemustakanya; 3) merupakan perangkat lunak open-source; dan 4) aplikasi banyak digunakan di perpustakaan perguruan tinggi di Padang. Selain itu, UIN Imam Bonjol Padang telah memiliki data center yang dikelola oleh UPT Teknologi Informsi dan Pangkalan Data (TIPD) sehingga perpustakaan tidak membutuhkan staf khusus yang mengelola aplikasi repositori tersebut. Laman repositori UIN Imam Bonjol Padang dapat diakses di http://repository.uinib.ac.id/.

Menurut Beazley (2010) bahwa kekuatan nyata dari Eprints terletak pada kemudahan penggunaannya bagi pengguna akhir dan administrator. Mengirimkan dokumen dalam Eprints sangat mudah. Pengguna cukup memasukkan metadata seperti jenis dokumen, judul, nama penulis, tanggal, dan lain-lain. Metadata yang diperlukan dapat dipilih oleh administrator. Formulir ini mudah dikustomisasi oleh administrator, sehingga hanya bidang yang relevan dengan koleksi tertentu yang disajikan kepada pengguna akhir. Pengguna dapat mengelola dokumennya, dan mengedit, memperbarui, dan menghapus dokumen dimungkinkan setelah pengajuan (meskipun administrator dapat membatasi fungsi-fungsi tersebut).

Meskipun Eprints tidak mendukung logika boolean, namun tersedia banyak pilihan pencarian serta fitur pencarian yang dapat dikustomisasi untuk menemukan dokumen dalam arsip ("Repositories Support Project"). Penjelajahan dapat dilakukan berdasarkan salah satu bidang metadata dalam koleksi, dan beberapa kriteria penjelajahan dapat digunakan. Misalnya, dalam menelusuri koleksi tesis, dimungkinkan untuk menelusuri melalui program studi dan kemudian memecah hasilnya berdasarkan tahun. Administrator memiliki kontrol atas kategori penelusuran mana yang tersedia bagi pengguna. Eprints adalah OAI-compliant, dan dokumen dalam arsip Eprints dapat diindeks oleh Google.

\section{c. Pemahaman Pustakawan}

Ketika pustakawan diminta, selama wawancara, untuk mendefinisikan komunikasi ilmiah, beberapa tidak memberikan jawaban yang jelas. Bahkan banyak di antara mereka yang baru mendengar istilah tersebut, dan menjelaskan bahwa mereka telah mendengar kalimat ini sebelumnya tetapi tidak dapat menjelaskan maknanya. Dalam kuesioner, pustakawan diminta untuk mendefinisikan istilah komunikasi ilmiah dengan menyetujui atau tidak setuju dengan enam pernyataan yang diberikan. 


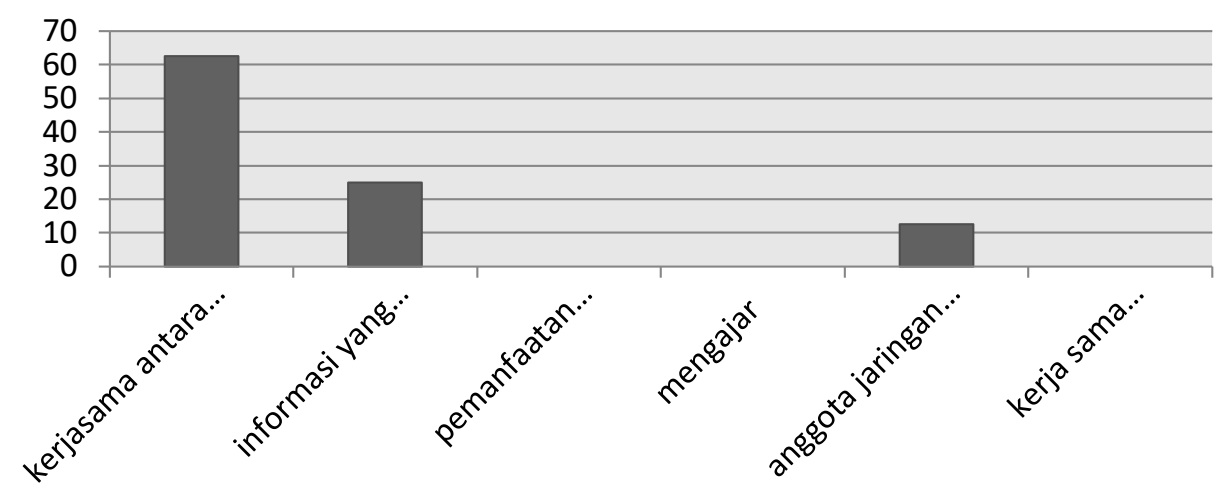

Gambar 3. Persentase pustakawan setuju dengan definisi komunikasi ilmiah

Kebanyakan pustakawan sepakat bahwa komunikasi ilmiah dapat didefinisikan sebagai kerjasama antara peneliti (62,5\%), informasi yang dikirimkan pada konferensi $(25,0 \%)$, dan anggota jaringan peneliti. Salah satu informan menyampaikan bahwa "Kami (pustakawan) menyadari akan kebutuhan dosen, tetapi baru sebatas kebutuhan untuk pengajaran dan bukan kebutuhan penelitian... Bahan bacaan yang dapat diakses secara online belum optimal." (RPustakawan 1).

Kepala Perpustakaan UIN Imam Bonjol Padang menjelaskan bahwa kolaborasi antara pustakawan dan dosen harus diprakarsai oleh masing-masing program studi. Dia merasa bahwa sampai saat ini, dukungan semacam itu kurang dan bahwa pustakawan tidak dapat memulai proses semacam itu sendiri, tanpa kerja sama dan pengakuan dari sisi akademis. Lebih lanjut dijelaskan bahwa kolaborasi tersebut dapat mempromosikan citra perpustakaan di mata dosen. Untuk itu para pustakawan harus mengembangkan keterampilan bidang ilmu, membangun hubungan yang lebih baik dengan dosen, dan memahami serta mengakui pentingnya hubungan tersebut. Proses tersebut akan membutuhkan kolaborasi antar dosen, memahami kontribusi potensial dari pustakawan dan berkolaborasi secara efektif dengannya.

\section{d. Masalah Teknis}

Tabel di bawah menunjukkan tantangan potensial masalah teknis.

Tabel 1. Tantangan Potensial Masalah Teknis

\begin{tabular}{|c|c|c|c|}
\hline No. & Tantangan & Defenisi & Rerata \\
\hline 1 & $\begin{array}{l}\text { Anggaran terbatas untuk } \\
\text { sistem dan peralatan }\end{array}$ & $\begin{array}{l}\text { Anggaran terbatas untuk pembelian sistem dan } \\
\text { peralatan yang diperlukan }\end{array}$ & 5,00 \\
\hline 2 & Kurangnya staf teknologi & $\begin{array}{l}\text { Ada kekurangan staf teknis untuk pengembangan dan } \\
\text { manajemen sistem }\end{array}$ & 4,93 \\
\hline 3 & $\begin{array}{l}\text { Komunikasi dengan } \\
\text { personel TI }\end{array}$ & $\begin{array}{l}\text { Sulit untuk berkomunikasi dengan personel UPT TIPD } \\
\text { ketika mengembangkan/memelihara suatu sistem }\end{array}$ & 4,63 \\
\hline 4 & $\begin{array}{l}\text { Kesulitan dalam backup } \\
\text { data }\end{array}$ & $\begin{array}{l}\text { Secara teknis sulit untuk membuat cadangan data bila } \\
\text { diperlukan }\end{array}$ & 4,16 \\
\hline 5 & $\begin{array}{l}\text { Desain antarmuka yang } \\
\text { berpusat pada pengguna }\end{array}$ & $\begin{array}{l}\text { Sulit untuk mengembangkan antarmuka yang memenuhi } \\
\text { berbagai kebutuhan pemustaka }\end{array}$ & 3,12 \\
\hline
\end{tabular}

\section{e. Masalah Pustaka}

Pustakawan berpendapat bahwa kurangnya motivasi pemustaka, terutama dosen untuk membagikan karya tulisnya pada repositori $(5,00)$. Selain karena belum adanya kebijakan serah simpan karya rekam dan cetak di UIN Imam Bonjol Padang, motivasi dosen mengirimkan karyanya ke repositori hanya ketika mengusulkan kenaikan pangkat fungsionalnya. Tantangan paling signifikan berikutnya adalah kekhawatiran pemustaka bahwa berbagi data mereka melalui repositori dapat menyebabkan masalah (4.91). Masalah yang paling dikhawatirkan oleh dosen adalah plagiasi karyanya oleh pemustaka lainnya. 
Dari hasil penelitian juga terungkap bahwa kebanyakan dosen masih beranggapan perpustakaan hanya sebagai tempat untuk belajar, tempat penyimpanan buku dan tempat untuk mengakses informasi ilmiah. Karena hal tersebut, kebanyakan dosen beranggapan bahwa perpustakaan belum sepenuhnya mampu memenuhi kebutuhan informasinya untuk tujuan penelitian. Bahkan sebagian besar dosen beranggapan bahwa perpustakaan tersebut lebih cocok untuk mahasiswa. Laporan yang dikeluarkan University of California Office of Scholarly Communication (2007) mendukung pernyataan tersebut bahwa kebanyakan dosen memiliki sedikit kesadaran tentang peluang untuk penerbitan akses terbuka, dengan terus mempublikasikan karyanya pada penerbit dalam bentuk tercetak. Selain itu, kurangnya penyelarasan proses penyimpanan dengan kegiatan sehari-hari yang rutin dari para dosen juga dapat berkontribusi pada kurangnya minat yang ditunjukkan oleh para dosen dalam menyetorkan karya ilmiahnya.

Beberapa orang dosen menyatakan bahwa mereka tidak pernah berpikir tentang melibatkan pustakawan dalam komunikasi ilmiah. Di sisi lain, para dosen juga merasa ragu, bahwa perlunya pustakawan terlibat dalam komunikasi ilmiah. Penyebabnya adalah para dosen masih meragukan kompetensi pustakawan dalam proses komunikasi ilmiah, seperti terungkap dari penyataan berikut.

"Saya masih kurang yakin dengan pustakawan, apakah mereka mampu membantu saya dalam memberikan informasi tentang artikel yang bisa bebas saya akses tentang penelitian yang sedang saya lakukan, apalagi memberikan masukkan pada rencana penelitian saya" (RDosen 3). "Pekerjaan pustakawan adalah untuk membuat informasi dapat diakses; mereka hebat di bidang ini ... Saya belum yakin pustakawan berpikir tentang komunikasi ilmiah, pustakawan hanya berpikir tentang pengembangan koleksi ... Sepertinya pustakawan tidak perlu terlibat dalam aspek komunikasi ilmiah." (R-Dosen 4)

\section{KESIMPULAN}

UPT Perpustakaan UIN Imam Bonjol Padang telah mengembangkan sarana komunikasi ilmiah dengan membangun repositori institusi sebagai akses terbuka. Namun, pemustaka masih belum yakin sepenuhnya pustakawan mampu mengelolanya. Di sisi lain, masalah teknis juga menjadi faktor penghambat pustakawan untuk mengembangkan repositori institusi sebagai sarana komunikasi ilmiah untuk pemustakanya. Selain itu juga perlunya kerja sama antara dosen dan pustakawan dalam mengembangkan komunikasi ilmiah. Kerja sama tersebut sebaiknya diprakarsai oleh masing-masing program studi melalui kebijakan tertulis. UPT Perpustakaan UIN Imam Bonjol harus mengembangkan pola komunikasi yang lebih baik dengan UPT TIPD.

\section{DAFTAR PUSTAKA}

Adewumi, A., \& Omoregbe, N. (2011). Institutional repositories: features, architecture, design and implementation technologies. Journal of Computing , 2 (8).

Association of Research Libraries. (2010). Envisioning research library futures: A scenario thinking project. Retrieved January 30, 2019, from Association of Research Libraries: http://www.arl.org/rtl/plan/scenarios/index.shtml

Berg, B. L. (2009). Qualitative research methods for the social sciences. Boston, MA: Allyn \& Bacon.

Bjork, B. C. (2005). A lifecycle model of the scientific communication process. Learned Publishing , 18 (3), 165-76.

Bjork, B., Laakso, M., Welling, P., \& Paetau, P. (2014). Anatomy of green open access. Journal of the Association for Information Science \& Technology , 65 (2), 237-250.

Bonn, M. (2014). Tooling up scholarly communication education and training. College \& Research Libraries News , 75 (3), 132-135. 
Budapest Open Access Initiative. (2002). Read the Initiative. Retrieved January 28, 2019, from Budapest Open Access Initiative: http://www.soros.org/openaccess/read.shtml

Carroll, M. W. (2011). Why Full Open Access Matters. PLoS Biology, 9 (11).

Dewatripoint, M., Ginsburgh, V., Legros, P., Walckiers, A., Devroey, J. P., Dujardin, M., et al. (2006). Study on the Economic and Technical Evolution of the Scientific Publication Markets in Europe. Final Report, European Commission, Directorate-General for Research, Brussels.

Drott, M. C. (2006). Open Access. Annual Review of Information Science and Technology , 40, 79109.

Epp, R. H., \& Segal, J. S. (1987). The ACLS Survey and Academic Library Service. College and Research Libraries News , 48, 67-68.

Griffin, S. (2013). New roles for libraries in supporting data-intensive research and advancing scholarly communication. International Journal of Humanities and Arts Computing , 7 (Supplement), 57-91.

Hahn, S. E., \& Wyatt, A. (2014). Business faculty's attitudes: open access, disciplinary repositories, and institutional repositories. Journal of Business \& Finance Librarianship , 19 (2), 93-113.

Hixson, C. (2006). If we build it, will they come (eventually)?: Scholarly communication and institutional repositories. The Serials Librarian , 50 (1-2), 197-209.

Johnson, P. (2014). Fundamentals of Collection Development and Management. Chicago: Americal Library Association.

Karla, L. H. (2008). Talk about talking about new models of scholarly communication. Journal of Electronic Publishing , 11 (1).

Kling, R., \& Callahan, E. (2003). Electronic journals, the Internet and scholarly communication. Annual Review of Information Science and Technology , 37, 127-178.

Kling, R., \& McKim, G. (1999). Scholarly communication and the continuum of electronic publishing. Journal of the American Society for Information Science , 50 (10), 890-907.

Lynch, C. H. (2003). Institutional repositories: Essential infrastructure for scholarship in the digital age. Portal: Libraries and the Academy , 3 (2), 327-336.

Mulligan, R. (2015). The Transformation of Scholarly Communications. Washington, D.C.: Association Research Libraries.

Prosser, D. C. (2005). Fulfilling the promise of scholarly communication - a comparison between old and new access models. In E. K. Nielsen, K. G. Saur, \& K. Ceynowa, Die innovative Bibliothek : ElmarMittlerzum 65 (pp. 96-106). Geburtstag: K.G. Saur.

Sauer, A. (2009). Why archivists should be leaders in scholarly communication. Journal of Archival Organization, , 7 (1-2), 51-57.

Tenopir, C., \& King, D. W. (2000). Towards electronic journals: realities for scientists, librarians, publishers. Washington D.C.: Special Libraries Association.

Yeates, R. Institutional repositories. Vine , 33 (2), 96-101. 